European journal of American studies

Special Issue: The North-West Pacific in the 18th and 19th Centuries

\title{
The Kosiyut Society of the Bella Coola Indians
}

\section{J.A. Jacobsen}

\section{(2) OpenEdition}

Journals

Electronic version

URL: https://journals.openedition.org/ejas/7813

DOI: $10.4000 /$ ejas.7813

ISSN: 1991-9336

Publisher

European Association for American Studies

\section{Electronic reference}

J.A. Jacobsen, "The Kosiyut Society of the Bella Coola Indians", European journal of American studies

[Online], 5-2 | 2010, document 4, Online since 18 February 2010, connection on 08 July 2021. URL:

http://journals.openedition.org/ejas/7813 ; DOI: https://doi.org/10.4000/ejas.7813

This text was automatically generated on 8 July 2021 .

Creative Commons License 


\title{
The Kosiyut Society of the Bella Coola Indians ${ }^{1}$
}

\author{
J.A. Jacobsen
}

1 In an article in Das Ausland No. 47, 1891, entitled “Travel Reports from Unknown Parts of British Columbia" by Philipp Jacobsen, ${ }^{2}$ repeated mention is made of the god Kosiyut, and therefore it may be of interest to learn more about the god and the secret society named after him.

2 Although the inhabitants of the Northwest Coast of America are collectively distinguished by a strict adherence to tradition, this conservative trait is most apparent in the residents of the stretch of coast from the Strait of Juan de Fuca to Mt. St. Elias. Here the mysterious customs passed down by the forefathers are so sacredly held that one could designate these tribes as especially religious, if this word did not signify too much for their tangled beliefs, which in no way can be viewed as a positive religion.

3 If the customs are precisely defined and well established in their forms by tradition, by contrast the ideas of the deity, especially concerning the god Kosiyut, who plays a large role both in the stories and in the life of the Indians, are so divergent that one has to conclude that they themselves have no definite, self-contained idea of the essence and workings of the god. Although not exhaustive, it seems indeed for the most part correct when he is denoted as the epitome of the inconceivable, holy, and ingenious. For all this is called Kosiyut by the Indians, just like the word tabu or pomali among the Polynesians and Melanesians.

4 All their gods take the form of monsters, half animal, half human, though are not limited to that, but rather can, according to want and circumstances, take any other form as well; however, they all seem to be inclined towards a certain favorite form, which makes them recognizable to the people. They are distinguished according to their residence: gods of the underworld, who are mostly imagined as sea dwellers, forest and mountain spirits, and gods of the upper world and clouds who occupy the heavens and are viewed by most tribes as the most powerful.

5 One of the latter is, according to the most widespread belief, the god Kosiyut, who has chosen the moon (En-kla-loi-killa) as his residence and is therefore identified with it. In 
addition, and corresponding entirely to the Indians' way of life, the god also has other dwelling places and is for instance also worshiped as the god of the forest.

6 Referring to the first image of Kosiyut, the Indians believe that when a lunar eclipse occurs, the moon has come down to earth in order to conduct a Kosiyut dance somewhere, and they therefore paint their faces black at the Kosiyut Ceremony. Also, this natural phenomenon excites their fear, which is grounded in the idea that the moon, as it gradually sheds its dark cover, throws the pieces of the cloak to earth, which results in the death of the one who is struck by them.

7 At the Kosiyut Ceremony the gods are represented by masks, which, according to the type of spirit (spirit of the forest, the mountain, the underworld, and the upper world) bear different facial expressions. Strangely, however, one sees little of the god after whom the ceremony is named. A characteristic presentation of the Kosiyut or Moon does not take place, and only the blacking of the face, which, however, is carried out with exacting precision by the dancers, alludes to it. And if one of the dancers in an especially artistically carved mask appears with clever and, to the onlookers, incomprehensible actions, then it is "Kosiyut."

8 The above-mentioned secret society stands in closest connection with these Kosiyut ceremonies, since those actively participating in them are members of the Kosiyut Society, which is widespread, especially on the aforementioned stretch of coast. It forms the first step for the remaining secret societies, since whoever wants to be accepted in another society must already be a "Kosiyut." Nevertheless, only a few select ones, mostly youths and marriageable girls (although married persons are not excluded), are accepted.

9 The novices are instructed by teachers, whose rank passes from father to son, only one, more rarely two, of whom usually lives in a village, in the mysteries and dances and who, just like the teacher, may not leave the village during the course of the first year. During the instruction year, they must also continually wear head- and neck-rings of red-colored bast, which they receive from the teacher. Also, they may not take these rings off during the time of ceremony, November and December. The face is always supposed to be painted black so that not a spot of face color is visible. This requirement is, however, not that precisely followed during the daytime, but is strictly observed with the approach of darkness. Trousers cannot be worn, but rather a clean woolen blanket, the dress of the fathers, is prescribed. A serious demeanor is an indispensable requirement. Laughing and joking is taboo, just as is associating with former playmates. Also, the novices may not go to the water during the first year, since through this they would frighten the fish from the coast.

10 The penalty for revealing the society's secrets is death by the old Kosiyut or a medicine man.

11 As already pointed out, the members of the Kosiyut Society have the advantage of being able to join the other secret societies, especially those of the medicine men and the association called "Allk" or "Nutlo-matla." Inspired by the deity, they have the capability of carrying out supernatural doings, possess to a certain extent a part of the power of the god, and show this in order to demonstrate their legitimacy. In this they sometimes produce truly notable feats for the onlookers, only a few of whom belong to the society. 
12 Because of this, white people who earlier attended such holy winter ceremonies believed that they witnessed medicine men since they excel in such productions and also make use of them in healing the sick. The Kosiyut never uses his talents for this since this is the affair of the medicine men, who above all are also Kosiyuts.

13 The feats carried out by the young Kosiyuts vary substantially, for each strives to bring something new. In addition to the experiment of being burned alive, which is popular among the medicine men too, the carrying of glowing-hot stones or glowing-hot iron in the bare hands is also popular. Others slit their stomachs open, have their head cut off or a lance jabbed through their body, and so forth.

14 My brother, who lives in this land, had the opportunity last winter to observe a feat at a Kosiyut Ceremony that appears actually incomprehensible. A young Indian carried out a dance naked and in the course of it asked the onlookers to throw a mat over him, which immediately stuck so fast to his back that four men, who pulled on the mat with all their force, and actually lifted the Indian up high with it, could not separate it from his body. Further attempts in front of the house were also without success. The mat remained as if grown into the dancer's skin, stuck to his back, without the connection being perceptible.

15 The female part of the Kosiyuts finds its force primarily in prediction and performs apparently astonishing feats thereof. the performance of apparently astonishing feats.

16 Thus, a Kosiyut woman in a village where the Kosiyut Ceremony was being held, and which lay a distance of four hours by water from another village where a ceremony was likewise being celebrated, gave a very detailed account of everything that was occurring at the ceremony at the same time, and her statements appeared to be completely correct, when participants of the ceremony returned to the village and were asked about the course of events at that ceremony.

17 The summer passes in exercises and instruction and the time arrives when the initiates are supposed to see the awaited spirit Noa-kinem. If they see him, then it is time for bustling activity: the house is tidied up, that is, the poles and mats that separate the sleeping places of the individual families from each other are removed, the floor, made of stamped earth, is leveled everywhere, and the necessary firewood is chopped and piled in the middle of the house and at the approach of darkness set alight. Then the dance begins.

18 Most often an old woman sits down by the fire and from time to time pours some oil from a large tube-like container made of seaweed into the flames, which as a result flare up to the roof, dazzlingly lighting the dance scene.

19 The dances of the Kosiyut belong to the so-called Underworld Dances, since the Kosiyut is generally inspired only by the god of the underworld, whose reception the ceremony glorifies. Upper world dances are performed more rarely, but in any case only on the fourth and last feast day, as we will show below.

20 Hence, upon the report that in this or that village a dance has begun, the question can be heard from the Indians: "Is it a dance of the underworld or of the clouds?"

21 During the first three days of the Kosiyut Ceremony, the novices dance with blackened faces and the aforementioned red head- and neck-rings. They are the main persons who - under the leadership of their teacher, the old Kosiyut, who functions here as master of ceremonies - carry out the first and last dances, which, as already mentioned, are dances of the underworld and are called "Di-kenk-di-nachom." The older Kosiyuts 
are only allowed to dance in these novice dances if the master of ceremonies calls out their songs.

Acceptance into the society and these days of the first ceremony form the high point in the life of the young Kosiyut. He fondly thinks back upon it and talks of it with pride well into old age.

23 On the fourth day, which concludes the festival, the visit the spirits of the underworld, led by Noa-kinem, their leader, as well as those of the forest and the mountains, pay to the most powerful god of the upper world, called Al-kon-dám, or Mess-mess-salánik according to another version, is performed. All participants dance in masks which, besides the actual god masks, are characteristic of the family traditions of the dancers. Flutes are also used, through the sounds of which the dancers indicate the voices of the gods.

24 A mask that represents a female forest spirit ("Anu-li-kutsai"), with a laughing face, slanted eyes, and a head tapering upward, opens the dance. This spirit speaks a foreign language and has the power to lure people to all dances, but especially to the Kosiyut Dance. As soon as someone is inspired by it to dance, the sound of a small flute can be heard.

25 Of the outstanding god masks, that of the thunder god Saiyul should be emphasized. Its voice is represented by a flute, while the roll of thunder is imitated by a large chest filled with stones. Further, Al-kon-dám, is imagined by the Indians to look like a European, and his mask always shows half closed eyes. He sits enthroned above the clouds in the rising sun, which is called Sinek and is worshiped as his son. ${ }^{3}$ Among the following dances the Sinakomek is also notable.

26 The one dancing wears a crown-like head adornment made from the whiskers of the sea lion. From the back of it hang many ermine pelts, while its cavity, which is open at the top, contains white eagle down, which is blown out through the movements of the dancer and is supposed to produce the impression of a snowstorm. Dances of the gods' animal servants, like the eagle, raven, wolf, bear, and so on, follow in the corresponding masks, and the laughing forest spirit Anu-li-kutsai concludes the ceremony with a last dance, which in Bella Coola, Kimskwit and Tallio begins at precisely the same time and likewise ends punctually in the three villages. This happens because the Indians believe that the god Noa-kinem enters and leaves the three villages at the same time.

27 After the end of the ceremony the small, easily made masks are thrown into the fire by the dancers with the cry "Woh-hoi!" The larger, finely carved ones, by contrast, are preserved in concealed places.

28 With the Kosiyut Ceremony, which according to our chronology usually falls between Christmas and New Year, all holy solemnities and therewith also those of the other secret societies, which begin in November, reach their end among the Bella Coola Indians, and the Kosiyut now, free from all constraints, once again goes about his usual business.

The following myths form the basis of the solemnities:

30 The ruler of the underworld, the mighty Noa-kinem, who lives in a land far to the west beyond the sea, where the salmon stay during the winter, turns to the east in the month of December, where he wishes to visit the powerful god Al-kon-dám (also called Mess-mess-salánik), who lives above the clouds in the sunrise. In doing so, he comes to 
the coast of British Columbia. However, he has been seen and observed on the trip for weeks by the spirit-seers, that is, the Kosiyuts.

31 On the fourth day after his departure, he lands with his great retinue on a point of land, rests here for four days, then travels on farther to the east to land again on a point of land. At this spot, he is greeted by some old Kosiyuts, as well as by forest and mountain spirits who bring their powerful ruler tribute, which consists of salmon, and the favorite food of the god is placed in his canoe.

32 After the passage of another four days, he continues his trip and lands on the third point of land, where he is seen by the forest spirit Deck-dokon-mem, the most vigilant spirit in the Bella Coola valley, who now alerts all the remaining spirits who have been sleeping deeply until then.

33 After four more days, Noa-kinem lands directly at Bella Coola village, which of course is seen only by the Kosiyuts. Immediately two helping forest spirits appear, one of whom, Amsta-glis, comes forth to tie up the canoe of the god. If Noa-kinem permits this, then this is seen as a bad sign, for no salmon will come to the river the following year.

34 According to the belief of the Indians, the availability of salmon on these coasts is connected to the arrival of Noa-kinem: if the god does not come, then the salmon also stay away. If on the other hand the god rejects the service of Amsta-glis and the other god, Ab-sulla-kai, ties up the canoe, then the salmon will arrive in great numbers in all rivers. If Noa-kinem now disembarks, he will order the residents of the village to bring stakes for making a weir on the river and to dress themselves in sun rays. ${ }^{4}$ The hummingbird comes and builds causeways to protect the canoes of the god and his retinue.

35 Led by Anu-li-kutsai (the laughing god face), the deity who entices dancing, the spirits of the forest appear, and in the presence of Noa-kinem, the Kosiyut Dance of the novices then begins. When the four feast days are over, the god prepares to continue his trip to Al-kon-dám. The spirits help him with this and present their tribute. Indeed, even the mighty Noa-kinem is not invulnerable to adversities, for a spirit in the form of a rat can steal a large part of the gifts.

36 In the last days of December, Noa-kinem leaves the village with the spirits and goes to visit Al-kon-dám, followed by all animals, from the largest to the smallest. The festival there, however, cannot begin until Sinek, the sun, the most distinguished of the guests, has arrived. The place of honor at the table of the gods is ceded to him and salmon is set before him. Otherwise the salmon would stay away the next year. Sinek is the last of the guests arriving at Al-kon-dám's dwelling and the first to leave.

37 In this regard the Indians say, when the sun is not very visible at the end of December and beginning of January, it is with Al-kon-dám. They refrain, however, from saying anything bad about this, for loose talk is punished. A legend reports that two Indians, who once found fault with the long hesitation of the sun, became insane through the power of the sun punishing them for their sacrilege. As, according to the Indians' belief, the souls of the animals stay with Al-kon-dám too, the time is used for hunting, because then animals are then supposed to be soulless and easily bagged.

38 Another son of Al-kon-dám now performs a dance in honor of the guests. He is considered the most skillful dancer among the gods, and the young Kosiyuts pray to him, that he bestow on them the gift of dance. In Al-kon-dám's house is a large room 
behind the sun's place of honor, which is occupied by the highest attendant spirit, Dam-dam-klimsta, whose task it is to receive the souls of dead people. He later brings them to earth where they are born again in a new body through the first female member of their family. The belief in this rebirth of the soul is a generally widespread one, though the Indians imagine this rebirth to be limited to prominent medicine men and a few celebrated people. They call such a reborn person Ailt-kwakem-dam-damklimsta, that is, "the good Indian reborn through Dam-dam-klimsta."

39 In the further course of the festival the sun dances and then follows the Sinakomek, which is a dance of the clouds. To distinguish it from the Kosiyut dance, it is called Dikleuck-di-nachom. Then all the animals dance, each in its own form, and Anu-li-kutsai, the laughing face, brings the dance to its conclusion.

40 At the Kosiyut Ceremony, the dancers fall into a kind of trance and believe they are at the real ceremony of the gods in Al-kon-dám's house.

41 How deeply rooted the beliefs and their related customs that have been handed down by their fathers are in these Indians is quite apparent in the precision and zeal with which the teacher instructs the Kosiyut candidates, who for their part are the most ardent pupils and have endeavored to assimilate the unabridged teachings. Of course, the remoteness of the villages, as well as the extraordinarily magnificent nature of their surroundings, is also very suitable for further mysterious teachings. This would explain why persistent mission work has registered so little success among these Indians. Both Catholic and Protestant missionaries have been able to accomplish little in spite of 20-year-long efforts among the tribes, for example, the Quakjutl [Kwakiutl]. The old belief is just too tightly bound to their existence and dealings. It even remains alive in cases where the tribes have already professed Christianity for a long time.

In the summer of 1886 I was in a Quakjutl village and had the opportunity to experience an example of this.

43 One day a large canoe landed at the village. The occupants of the canoe, men and women, were going to Victoria. They belonged to the Tschimpsian [Tsimshian] tribe of Indians and were from a village whose occupants had professed Christianity for 20 years. Scarcely had the canoe touched the shore than the Christian Tschimpsians painted their faces red, precisely in the Indian manner, and the Quakjutl chief went to the shore with his people to greet the foreigners. In the now ensuing conversation, which I witnessed, a Tschimpsian chief's wife said: "As we passed the village of Fort Rupert today we heard the old beloved sound of the drums; we were so carried away by it that my companions and I involuntarily began to dance."

\section{NOTES}

1. This article was originally published as Der Kosiyut-Bund der BellaCoola-Indianer. In Das Ausland: Wochenschrift für Erd- und Völkerkunde 65(28):437-441, 1892.-Translator. 
2. The article alluded to here was originally published as "Reiseberichte aus unbekannten Teilen Britisch Columbiens." Das Ausland:

Wochenschrift für Erd- und Völkerkunde 47:921-928, 1891. It appears in translation as "Philipp Jacobsen in British Columbia" in British Columbia Historical News 37:2:20-27, 2004.-Translator.

3. It is notable that the great spirits who live in the east on a large, beautiful Island, where schools of fat salmon cavort in four mighty streams (the Canaan of the Indians), and who likewise have a white skin color are used as slaves by the Indians. The names of these four spirits are: Mess-mess-salánik, Julo-timot, Metle-fik-set, and Metla-puli-set.J.A.J.

4. This supposedly means: to go naked.-J.A.J. 